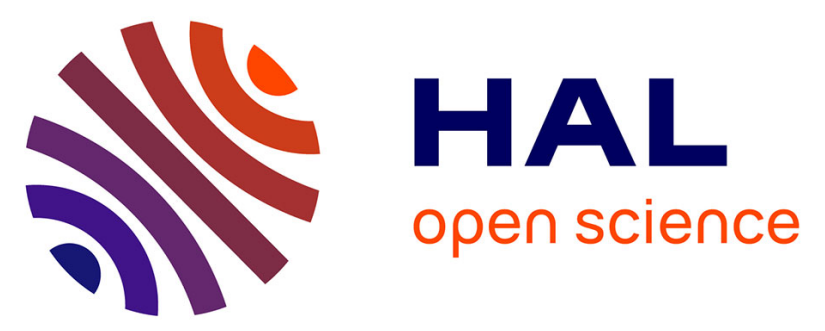

\title{
Can raw milk cheese and pasteurised milk cheese coexist? Unthinkable or never really considered?
}

Christine de Sainte Marie, Mariagiulia Mariani, Morgane Millet, Claire Cerdan, François Casabianca

\section{- To cite this version:}

Christine de Sainte Marie, Mariagiulia Mariani, Morgane Millet, Claire Cerdan, François Casabianca. Can raw milk cheese and pasteurised milk cheese coexist? Unthinkable or never really considered?. Review of Agricultural, Food and Environmental Studies, 2020, 101 (2-3), pp.287-309. 10.1007/s41130020-00106-y . hal-03107672

\section{HAL Id: hal-03107672 \\ https://hal.science/hal-03107672}

Submitted on 12 Jan 2021

HAL is a multi-disciplinary open access archive for the deposit and dissemination of scientific research documents, whether they are published or not. The documents may come from teaching and research institutions in France or abroad, or from public or private research centers.
L'archive ouverte pluridisciplinaire HAL, est destinée au dépôt et à la diffusion de documents scientifiques de niveau recherche, publiés ou non, émanant des établissements d'enseignement et de recherche français ou étrangers, des laboratoires publics ou privés. 


\title{
CAN RAW MILK CHEESE AND PASTEURISED MILK CHEESE COEXIST? \\ UNTHINKABLE OR NEVER REALLY CONSIDERED?
}

\author{
Version 4 - final, June 2020 \\ Christine de Sainte Marie 1, Mariagiulia Mariani ${ }^{\mathbf{2}, 3}$, Morgane Millet ${ }^{3}$, Claire Cerdan ${ }^{\mathbf{3} 4}$, \\ François Casabianca ${ }^{3}$ \\ ${ }^{1}$ INRAE, UMR 1048 SAD-APT \& UMR IRISSO, Univ. Paris Dauphine \\ ${ }^{2}$ CIRAD, UMR INNOVATION, Univ. Montpellier, CIRAD, INRA, Montpellier SupAgro \\ ${ }^{3}$ INRAE, UR 45 Laboratoire de Recherche sur le Développement de l'Élevage \\ ${ }^{4}$ CIRAD, UMR INNOVATION, Saint-Pierre (Réunion) \\ Corresponding author : christine.de-sainte-marie@inrae.fr; christinedesaintemarie@gmail.com
}

\begin{abstract}
This article examines the contentious issue of the coexistence of cheese made from raw milk and cheese made from pasteurised milk in areas of protected designation of origin (PDOs). The French PDO system is held to be the benchmark of the international system of Geographical Indications (GIs). Drawing on the multi-level perspective framework of socio-technical transitions, we conceptualise PDO cheeses as a "niche" nested within a dominant regime that promotes pasteurisation as the standard technology to control pathogens in milk. Careful examination of statistical data and the specifications for PDO cheeses shows that raw milk is experiencing an upturn in domestic production, which we relate to the reinforcement of the regulatory frameworks governing protection of GIs. We investigate more fully the steady increase in raw milk use by studying two contrasting cases of PDO cheeses (Saint-Nectaire and Ossau-Iraty), in which the confrontation between technologies is internalised. Analysis of local innovation pathways highlights a series of key decisions that strengthen the position of raw milk from the farm to the marketplace, namely grass-feeding, limiting herd productivity, technology-specific identification marks and redistribution of decision-making power among stakeholders. Regulatory mechanisms that counterbalance the pressures of the regime by strategic management of the "terroir" niche are identified and discussed. We argue that shifting the focus from niche regime interaction towards the internal dynamics of niches sheds light on the conditions of a coexistence of apparently antagonistic models of production in agrifood networks.
\end{abstract}

Key Words: coexistence, cheese, geographical indications, raw milk, terroir niche, strategic niche management 


\section{INTRODUCTION}

In 2018 a turning point was reached in the so-called "Camembert war" being fought over the status of the iconic French cheese. Normandy Camembert is a cheese made from raw milk that was awarded a protected designation of origin (PDO) in 1983. In the early 2000s, the dairy multinational Lactalis and the cooperative of Isigny, which account for $80 \%$ of the total production of Camembert, were pressing for the designation to allow the cheese to be made from pasteurised milk, on the grounds of safeguarding consumer health (Sciolino, 2007). Their case was dismissed. As a result, they decided to no longer use the designation of origin, preferring instead the term "Made in Normandy", which simply means that the cheese-making factory is located in the administrative region of Normandy (Casalegno and Laske, 2016).

The debate then moved into the commercial arena, where the two types of production, one using raw milk and granted the designation of origin, and the other using pasteurised milk and Made in Normandy, now existed side by side. The Organisation for the Defence and Management of the Normandy Camembert failed in its court challenge to ban the use of the term "Normandy" by producers who were unfairly piggybacking on the reputation of the Camembert made from raw milk. Institutional mediation led to a compromise proposal: the industrial producers would give up the indication "Made in Normandy" and those using raw milk would accept that cheese made from pasteurised milk was entitled to the PDO, in return for baseline specifications on milk production and the cheese-making process. Raw-milk cheese-makers, a large number of whom use milk from Normande cows raised on Normandy grasslands, would have a distinctive label on their product indicating that it is "véritable" Camembert de Normandie ("genuine" Normandy Camembert).

This compromise was strongly opposed in an open letter signed by personalities from the world of gastronomy. They stated, "All producers whose cheese has the designation of origin and who have decided to use pasteurised milk, which means opting for greater volume, have debased quality without in any way settling the question of a fair income for dairy farmers. Only the large companies have benefited."(Libération, 2018; Peltier, 2018). Advocates of raw-milk Camembert, supported by the international Slow Food movement, claim that French PDO cheeses, under the influence of industrial producers, have been discredited, leaving farmhouse cheese as the sole "real" terroir product.

Against this background, cheese production takes on the aspect of a confrontation of two types of milk, whose outcome will see one of the two forcing the other to disappear. The opposition between pasteurised and raw milk echoes the divergence between cheeses made in a dairy, the epitome of standardised, aseptic industrial production, and farmhouse cheeses, archetype of a quality product with a terroir pedigree. Moreover, the PDO system, which was supposed to defend terroir products, would tend to reinforce the imbalance and contribute to the disappearance of raw milk cheese (Richez-Lerouge, 2017). Seen in this framework, the existence side by side of two opposing models of cheese production would appear to be "unthinkable".

To go beyond this simplistic view of the world of cheese, this paper will examine the modalities of the coexistence of raw and pasteurised milk within the designations of origin in France. Our approach is based on the Multi-Level Perspective (MLP) framework and the theory of sociotechnical regime transitions. After assessing the status and consolidation of raw milk in PDO cheeses on a national level, we will develop the analysis by comparing the innovation pathways of two PDOs, Saint-Nectaire and Ossau-Iraty, which have long been authorised to use 
pasteurised milk in their production. The results of this cross-analysis will provide the base for a more general discussion of the dynamics of competition and complementarity between raw and pasteurised milk, and the tension between identification with a terroir and health risk management in dairy production. A systemic approach taking into consideration the overall productive resources and the mechanisms that regulate PDOs, seen as complex niches, will shed light on the conditions of a coexistence that has never really been considered by the advocates of "real" terroir cheese.

\section{CONSIDERING COEXISTENCE: THE STRATEGIC NICHE MANAGEMENT PERSPECTIVE}

We consider here the world of cheese as an area of research in which the dynamics of the coexistence of contrasting models and their confrontation is thrown into sharp relief. The right to produce and market raw milk cheese is regularly debated within professional organisations and at international forums (Sylvander and Biencourt, 2006; Licitra, 2010). The cornerstone of industrial dairy production, pasteurisation has been the dominant model of cheese-making since 1945. The robustness of the model owes much to the decisions of certain policy-makers or representatives of the dairy sector who, on the basis of rare but widely publicized events, consider that the risks incurred by the consumption of raw milk are unacceptably high (Ricard, 1998; West, 2008). However, the imbalance between the dominant model of the cheese industry and the subservient model of raw-milk cheeses, made according to traditional methods, has been redressed by a growing awareness of the limitations of the former (Paxson, 2008). The movement that highlighted the differences in the types of food production and supply, which Goodman saw as a "quality turn" (Goodman, 2003), had a driving role in the process of transition towards the promotion of raw-milk cheeses. In France and southern Europe, the transition was achieved mainly by the use of Geographical Indications (GIs), among which the protected designation of origin (Bérard and Marchenay, 2007; Trubek and Bowen, 2008; Barham and Sylvander, 2011). This measure did not challenge head on the dominant model but provided a niche within which the participants enjoyed a relative autonomy in the choice of their production methods.

There is currently no unified theoretical framework that accommodates the modalities and dynamics of the co-existence of these different cheese-making processes nor of farming and food provisioning models in general (Dumont et al., 2020). The Multi-Level Perspective (Geels, 2002; Geels and Schot, 2007; Schot and Geels, 2008), which is frequently used in transition studies (Markard et al., 2012; El Bilali, 2020), seems well-suited to our research. It situates the dominant food system (the regime) and alternative experiences (the niches) in a common analysis framework. The socio-technical regime is stable because it is based on a wellestablished set of standards, actors, policies and markets. The niches are constructed apart from the dominant rules and actors. This does not mean, however, that they are dissociated from the model of transition: they are perceived as spaces of incubation, as places where learning processes can take place and economic networks are developed. Their role is to foster the emergence and consolidation of alternative systems and breakthrough innovations.

Most transition studies focus on the relations between niches and the regime. In the graphical representation of the socio-technical transition of Geels and Schot (2007), the niches of innovation would bring about a transformation of the regime by progressively integrating it. The transformative potential of alternatives to the dominant system emerged as a focal point in the debate on transition to sustainability. Other studies have shown that certain niches develop 
in parallel to the regime and contribute to the emergence of a set of standards, actors, policies and markets (Schot and Geels, 2008; Turnheim et al., 2015). Their non-convergence with the regime and the absence of a shared horizon result in the creation of a patchwork of regimes (Lamine et al., 2012).

From their analysis of the Corsican clementine, which benefits from a GI, Belmin et al. (2018) proposed the notion of "terroir niche". This niche is considered to be complex because it contains elements of the dominant regime, such as the aim of producing large fruits and eliminating any visual defect, and elements contrary to the prevailing model, such as fruits picked with their leaves and on-tree ripening, which are based on the biophysical environment and local expertise. The accent is no longer on the relations between niche and regime but on the analysis of how tensions are regulated within a particular niche, in the light of works on Strategic Niche Management (SNM) (Schot and Geels, 2008; Raven et al., 2010; Köhler and et al., 2019).

In our case study, the promoters of pasteurisation clearly belong to the dominant regime. On the other hand, the producers and affineurs (cheese ripeners) of raw-milk cheese, who use quality labels (PDO in particular) as a leverage, cannot be considered as being totally outside the dominant regime. Currently, raw-milk cheeses are made by both independent producers, subsidiaries of large private companies, such as Lactalis and Savencia, and major cooperatives such as Sodiaal. In addition, pasteurisation is allowed in certain PDOs, which results in rawmilk and pasteurised milk cheeses being sold under the same name. This complex configuration of French PDO cheeses would be an incentive to go beyond the binary oppositions between industrial dairy producers and farm producers, raw milk cheese and pasteurised milk cheese and conventional and alternative models.

This could be achieved by the notion of a terroir niche, which encompasses the different modes of production that coexist in a given place. In the case of cheese, we will consider how the regime brings pressure to bear via food safety standards (absence of pathogenic bacteria in milk and cheese) and the promotion of pasteurisation as a blanket solution to satisfy them. Resolving these tensions depends largely on the methods of governance and the power relations in force (Turnheim et al., 2015; Torre and Traversac, 2011; Lamine et al., 2012). Belmin et al. (2018) show that the strategic management of complex niches is based on two complementary approaches. One consists in strengthening the ties with the place by drawing on local resources (Colletis-Wahl and Pecqueur, 2001) and the other consists in the establishment of protective mechanisms such as collective rules and controls (Raven et al. 2012). The authors maintain that the combination of these two approaches will guarantee the long-term sustainability of the niche either by preventing it from being absorbed into the regime (which in our context would mean all cheeses being made with pasteurised milk) or by excluding from the niche actors not able to meet the requirements of raw milk production.

To analyse the coexistence of different production models within the world of cheese, our hypothesis posits the governance of PDOs as the condition for a strategic management of the terroir niche that would make it possible for raw milk and pasteurised milk to develop side by side over the long term. We will assess to what extent this governance combines protective mechanisms with the mobilisation of place-based resources to ensure the durability of the terroir niche. 


\section{MATERIAL AND METHODS}

\subsection{Make an overview of French cheese PDOs through the prism of raw milk}

Information about raw milk production is absent from available statistics about French PDO cheeses, with the exception of farmhouse cheeses. The "farmhouse" designation is specific to France. It refers to "cheese made according to traditional methods, by agricultural producers processing only milk from their own herd and within the farm premises." (Decree "Fromage", 1988). Farmhouse cheeses are therefore considered as exclusively made from "raw milk", for which French regulations have given a strict definition that has been adopted in the European Union: (milk) "which has not been heated beyond $40^{\circ} \mathrm{C}$ or undergone any treatment that has an equivalent effect" (Council Directive 92/46/EEC, Art.2).

The main source of data on raw milk cheeses is the annual dairy survey conducted by the Ministry of Agriculture since 1991 (Agreste). However, information on farmhouse and PDO cheeses is lacking in this survey, which only records the quantities of raw milk cheese marketed by production units collecting and/or processing milk supplied by farmers.

To assess the place of raw milk in PDO cheeses we first compiled the texts relative to each published in the official journals of the French Republic and the EU. We identified the PDOs that allow pasteurisation or thermisation (milk heated at a lower temperature, between 57 and $68^{\circ} \mathrm{C}$ ) and those in which the use of raw milk is in constant progression. Two PDOs, SaintNectaire (SN) and Ossau-Iraty (OI), were chosen as case studies. Both are semi-hard, pressed and uncooked cheeses with a comparable risk of exposure to pathogens. In contrast, they differ in the use and non-use of raw milk by local dairies.

\subsection{Analysis grid of the socio-technical pathways of the two PDOs}

The analysis grid of the socio-technical pathways of the two PDOs was organised around three major elements: (i) the set of regulations and how they evolved, (ii) technical and commercial differences, and (iii) the flow of material and information within the niches. Original data were collected by Millet (2019) and Mariani (2019), who interviewed the different stakeholders involved in the OI. For data on SN, we drew on findings documented by Tijms (1976), Ricard (1994) and Brosse et al. (2014). For both PDOs, we completed the data by targeted interviews with representatives and technicians from the Organisation for the Defence and Management of PDO, which henceforth will be designated by its French acronym, ODG.

\subsection{Presentation of the case studies}

\subsubsection{Raw milk cheese made only by farmers: Saint-Nectaire}

Saint-Nectaire is a cow's milk cheese produced in the volcanic area of the Massif Central in the centre of France, where it is ripened for at least 4 weeks. In 2015, there were 212 producers of farmhouse SN, of whom 65 ripened all or part of their own cheese production. The others sold their cheese green 8 to 10 days after curdling to one of the 23 affineurs working in the delineated production area. In parallel, 8 enterprises collected the milk of 391 farmers, which was delivered to 4 dairies that produce SN made exclusively from pasteurised milk. Two out of these 4 dairies are owned by large industrial groups: Lactalis, which bought a family dairy (Wälchli) in 2010, and Sodiaal, which took over a union of cooperatives (3A) in 2013. These two market leaders also own ripening cellars and packaging facilities. They exist alongside 
specialised cheese affineurs, one of whom (Dischamps) made an upstream investment in the purchase of an independent dairy in financial difficulty.

With 13763 tonnes of cheese put on the market in 2016, Saint-Nectaire is the fourth largest PDO cheese and the first farmhouse cheese in France. It is noteworthy that $90 \%$ of milk that complies with the PDO specifications is transformed into SN. Moreover, since 2016 the production of farmhouse SN has overtaken that of dairy SN [Figure 1]

Figure 1: Evolution of the production of Saint-Nectaire in tonnes 1995-2017
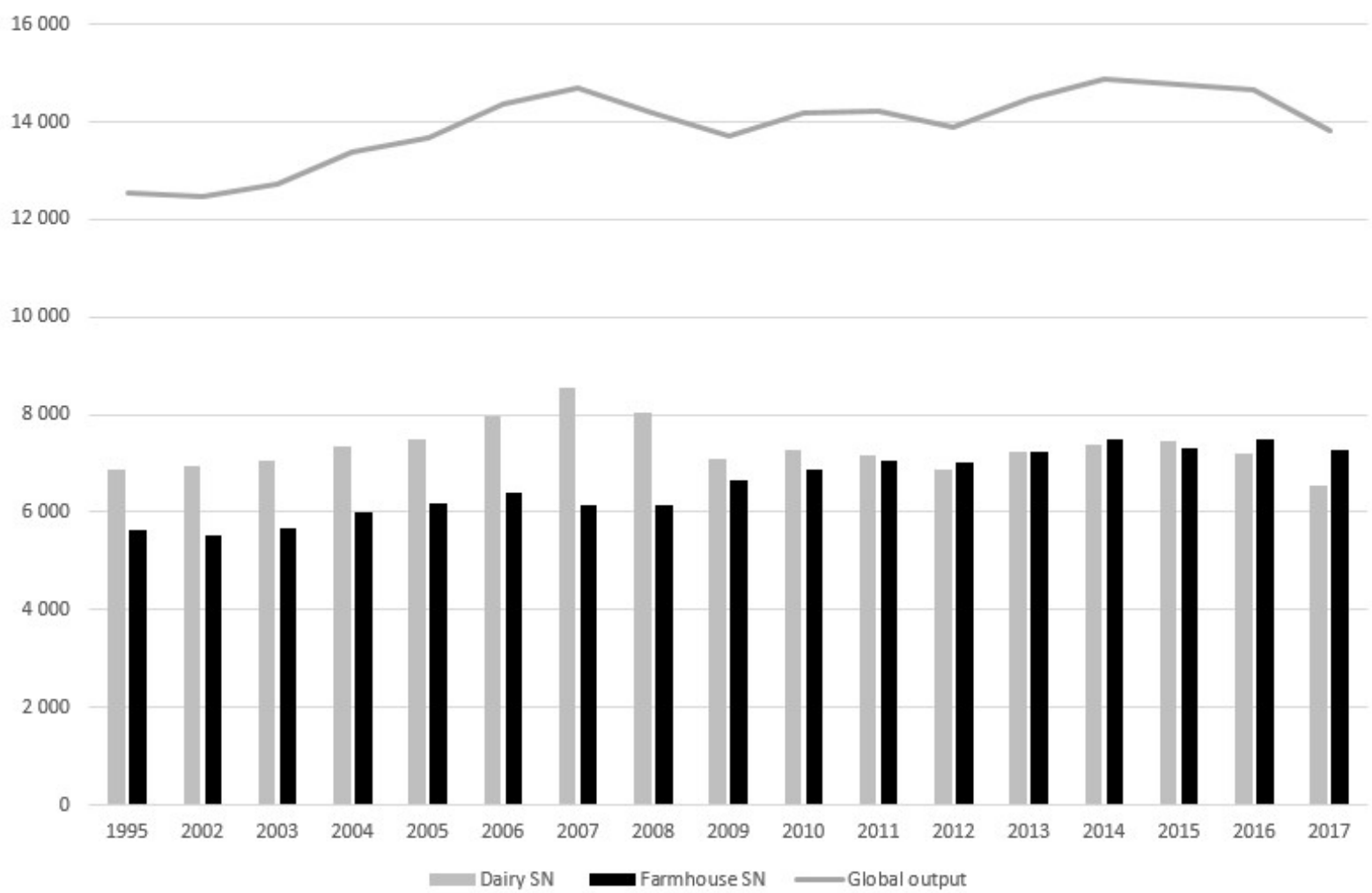

Source: ODG Saint-Nectaire

\subsubsection{Farmhouse and dairy raw milk cheese: Ossau-Iraty}

Ossau-Iraty is cheese made from ewe's milk. It is produced exclusively in the Pyrenees valleys of Béarn and the Basque country, where it is ripened for at least 2 to 4 months. In 2017, there were 156 producers of farmhouse OI, 160 milk producers, whose milk was processed by 11 cheese dairies, and 10 affineurs. Subsidiaries of the large dairy groups, Savencia, Lactalis and Sodiaal, work only with thermised milk and account for about $85 \%$ of the local production of ewe's milk cheese (2014). Lactalis has also invested in the ripening of farmhouse cheeses through one of its subsidiaries (Mattocq).

Dairy production in 2016 amounted to 3790 tonnes of PDO cheese (85\% in volume) as compared to 447 tonnes for farmhouse OI. Unlike SN, raw milk is also processed by small independent dairies. Raw milk OI accounts for almost $18 \%$ of tonnage sold, of which $8 \%$ is made in dairies, and its market share is steadily growing [Figure 2] 
Figure 2: Evolution of the production of Ossau-Iraty in tonnes 1991-2016

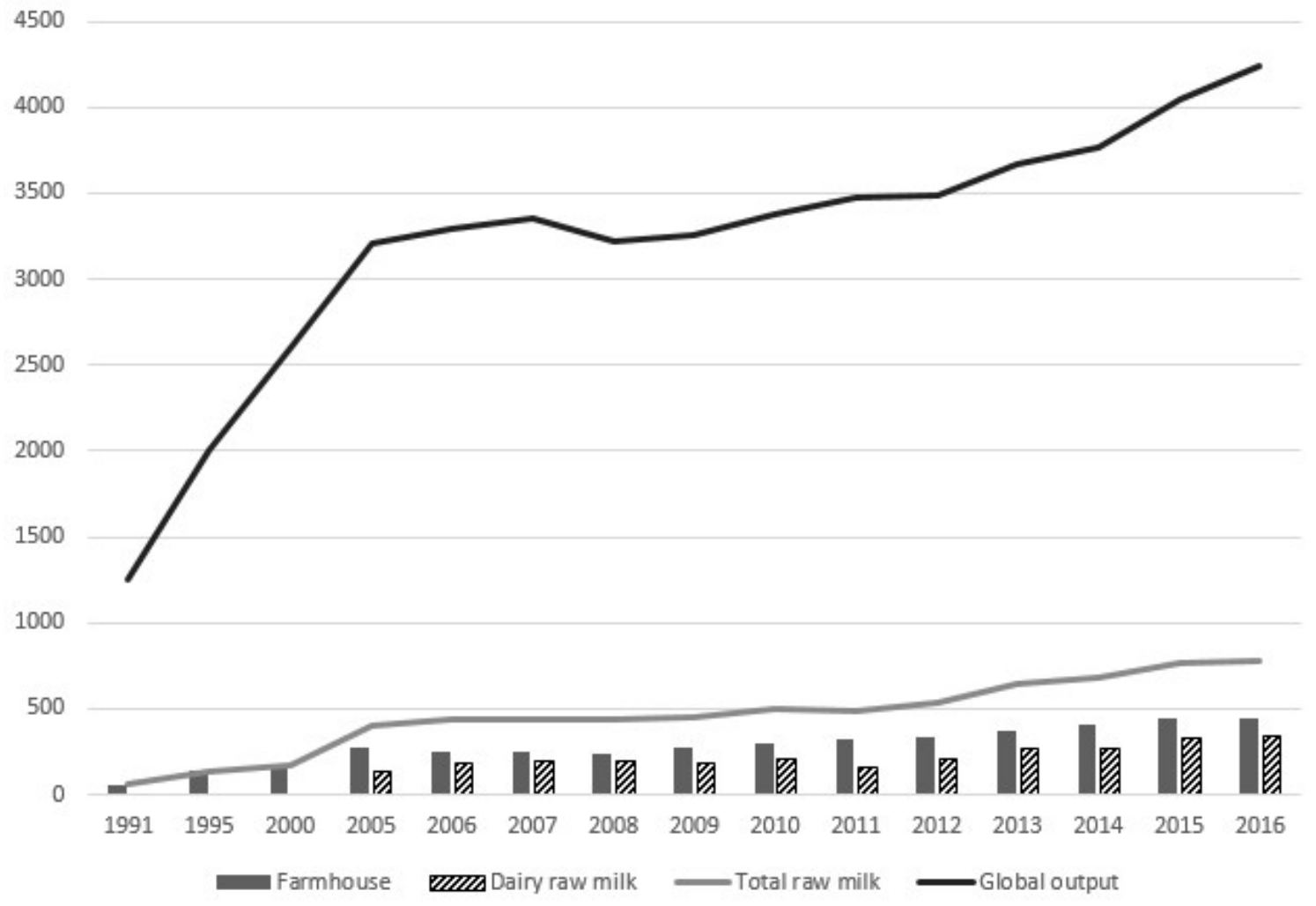

Source: ODG Ossau-Iraty

The production of dairy raw milk cheese is based on farming requirements that go beyond those of the PDO. This development is driven by contracts with large retailers, as in the case of the Agour cheese dairy, or business initiatives, as in the case of Azkorria and Garazi cheese dairies.

\section{3 - RESULTS}

Our results show that the use of raw milk in French cheese production is on the increase. We relate this trend to changes in the institutional and regulatory frameworks governing the protection of designations of origin, at a time when their market is expanding. In-depth analysis of the innovation pathways of SN and OI highlights a series of key amendments to the two PDO specifications that strengthen the position of raw milk from the farm to the marketplace, namely grass-feeding, limiting herd productivity and technology-specific identification marks. This shift goes along with a redistribution of power between stakeholders in the governance of the terroir niche, which makes it possible to regulate the flow of milk, cheese and resources between local operators. 


\subsection{The national context: raw milk use in French PDO cheeses consolidated}

To date, 46 French cheeses are protected by a PDO. Of these, 27 with a high tonnage production, such as Comté, Roquefort and Reblochon, are made exclusively from raw milk. In none of the 19 designations that allow pasteurisation is the use of raw milk forbidden.

Analysis of French PDO cheeses through the prism of raw milk identifies different phases of tension alternating between alignment with, and opposition to, pressure exerted by the regime, which claims pasteurisation as one of its main driving forces.

France was the first country to introduce legislation protecting the geographic origin of agricultural and food products, by the law of 1919, since when it has become firmly established at an institutional level. The system was structured in the interwar period around wine and the concept of terroir. It was only extended to cheese in 1955 (Delfosse, 2007).

Until the beginning of the 1950s [Figure 3, column 1], the use of raw milk was the norm in traditional cheese production. The designations of origin existing before 1955 had been awarded by court judgement following a suit for unfair competition brought by local cheesemakers against industrial producers in other regions of France. In 1955, the Ministry of Agriculture became the authority responsible for granting cheese PDOs. In line with government policy of the day, pasteurisation was implicitly authorised for designations awarded thereafter (column 2). In a period of modernisation of the cheese-making industry and unification of the national milk market, the production of cheese made exclusively from raw milk became an instrument of development of livestock farming and the competitiveness of craft businesses in less favoured areas. This strategy was adopted by producers of Reblochon and Beaufort cheeses in the Savoy region, following the lead of the Comte PDO and, in contrast to the Cantal and Maroilles PDOs, by defenders of Salers and Laguiole cheeses in midmountain areas.

Between 1975 and 1990, cow milk cheese production underwent a shift when pasteurisation was allowed in only 2 of the 7 PDO recognised during the period. More significantly, 3 out of the 5 "exclusively raw milk" PDOs were cheeses made in lowland areas (Brie de Melun, Brie de Meaux and Camembert de Normandie). In contrast, the trend for goat milk cheeses was the opposite. The oldest designations granted, Selles-sur-Cher (1975) and Chavignol (1976), were made exclusively from raw milk whereas Picodon, Chabichou and Ste Maure de Touraine, which came later, were not (column 3). 
Figure 3: Dynamics of raw milk use in French PDO cheeses according to the date of recognition

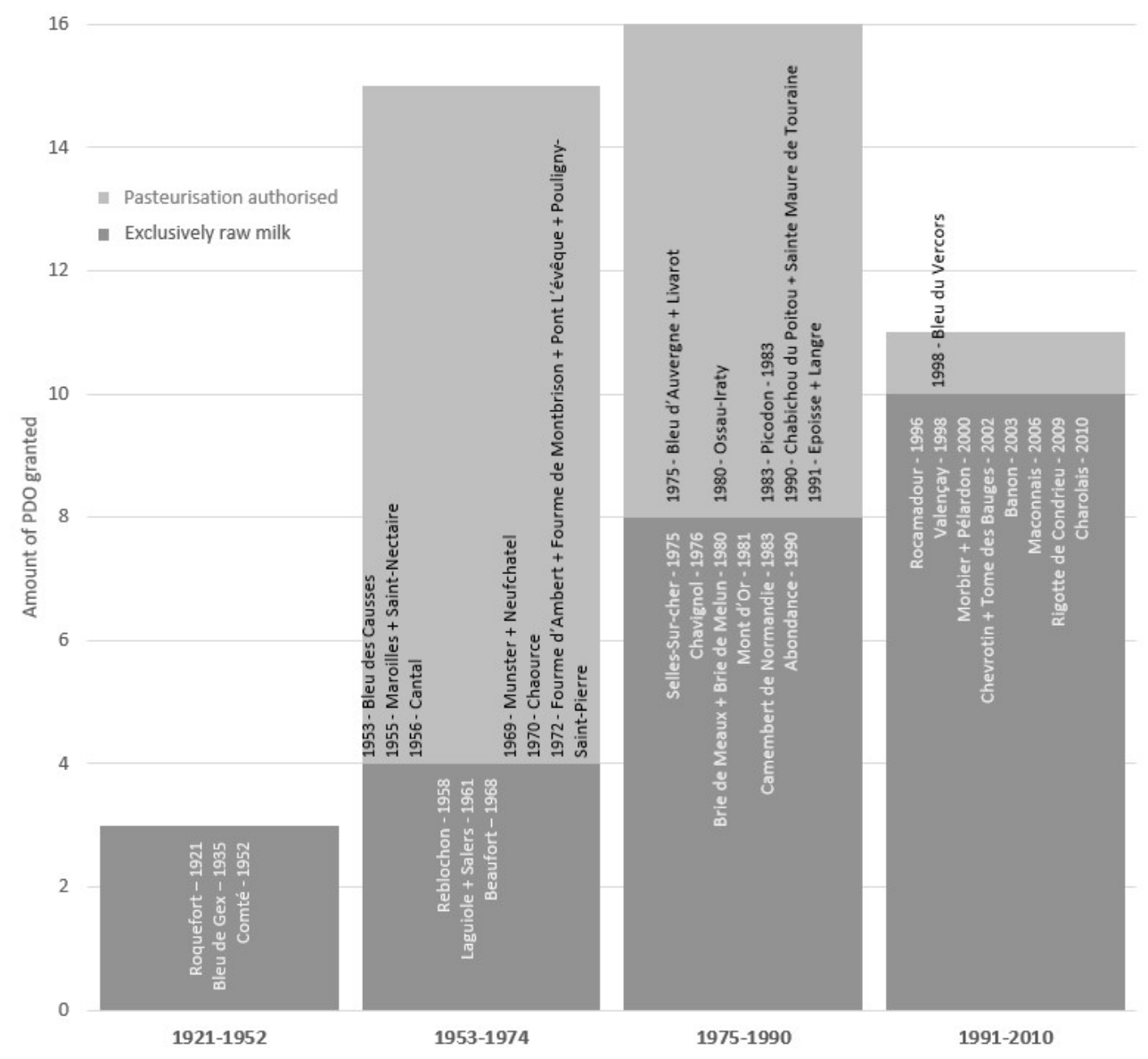

Source: Authors

Between 1991 and 2010 (column 4), all but one (Bleu du Vercors) of the 11 new PDOs were cheeses made exclusively from raw milk. They applied mainly to small or very small productions: less than 100 tonnes for goat's milk cheese (with the exception of Rocamadour) and less than 1000 tonnes for cow milk cheese (with the exception of Morbier). These deviations from the previous trend of alignment with the regime took place in the wake of the establishment of multilateral agreements on GIs. The aim of the French reform of 1990 was to disarm criticisms from certain member states of the EU and the World Trade Organisation that the designation of origin constituted a protection that had no real justification in a free-market regime. PDO cheeses were then placed under the jurisdiction of the National Institute of Origin and Quality, still known by its old acronym of INAO, an independent administrative body itself under the authority of the Ministry of Agriculture. To be registered with the European Commission, current and future PDOs had henceforth to provide evidence of their "promise of difference" (Le Velly, 2019) by demonstrating that "the quality or characteristics (of cheese) are essentially or exclusively due to a particular geographical environment with its inherent natural and human factors" (Council Regulation EEC 2081/92). The only new PDO granted between 2010 and 2018 was Charolais. In contrast, during the same period the specifications and governance of the existing PDOs underwent major changes. 
The consolidation of the use of raw milk in French PDO cheeses has been borne out by its increased volume of production (Table 1), which rose by 68830 tonnes between 1991 and 2017, whereas over the same period that of PDOs allowing pasteurisation decreased by 12800 tonnes. Of the 200431 tonnes of PDO cheeses marketed in 2017, almost three quarters were made exclusively from raw milk. Cross-checking with data from the Agreste survey shows that the 26 PDO cheeses made exclusively from raw milk accounted for $75 \%$ of the national production of ripened raw milk cheese marketed by dairies in 2017 . The production of raw milk cheese for the 19 PDOs that allow pasteurisation was only given for farmhouse cheeses. Its volume was nevertheless significant, representing almost $20 \%$ of production in the same year as against less than 5\% for PDOs made exclusively from raw milk.

Table 1: Evolution of the volume of raw milk used in French PDO cheeses (1991-2017)

\begin{tabular}{|lcccc|}
\hline & \multicolumn{2}{c}{ Exclusively raw milk } & \multicolumn{2}{c|}{ Pasteurisation allowed } \\
\hline & $\mathbf{1 9 9 1}$ & $\mathbf{2 0 1 7}$ & $\mathbf{1 9 9 1}$ & $\mathbf{2 0 1 7}$ \\
\hline All PDO producers & & & & \\
\hline Number & 15 & 26 & 19 & 19 \\
\hline Tonnage & 84970 & 145801 & 67441 & 54630 \\
\hline Farmhouse production & NA & 6100 & NA & 10411 \\
\hline Main PDOs, in tonnes & & & & \\
\hline Comté & 31500 & 57894 & - & - \\
\hline Roquefort & 19970 & 16184 & - & - \\
\hline Cantal & & & 16146 & 13186 \\
\hline Reblochon & 11400 & 15797 & - & - \\
\hline Saint-Nectaire & & & 11195 & 13815 \\
\hline
\end{tabular}

Source: INAO

These findings need to be tempered with the evolution of the production of French ripened raw milk cheeses between 1997 and 2017. After reaching its lowest point in 2007 (168 604 tonnes), raw milk cheese production returned to, and then exceeded, its previous level in 1997 (191604 tonnes) to reach 198680 tonnes in 2017, when it accounted for $15 \%$ of the overall production of French ripened cheese, irrespective of the milk used.

It is difficult, however, to conclude what role PDOs have played in the recovery in raw milk cheese production over the last decade. The increase in the number of exclusively raw milk PDOs was concomitant with a relative decline among some of the most important, such as the continued regression of Roquefort and the drastic fall in Normandy Camembert. The same trend was observed in PDOs such as Cantal that allow pasteurisation. However, certain guidelines have clearly emerged since PDO cheeses came under the jurisdiction first of the INAO and then of the European Commission. Evidence of particular ties with the terroir has strengthened the status of raw milk and its distinctive quality among French cheese designations. For cheeses that allow pasteurisation, new applications opted for the Protected Geographical Indication, a less demanding GI. Cross-analysis of the Saint-Nectaire (SN) and Ossau-Iraty (OI) PDOs will provide further insight into these general observations concerning the resurgence in the use of raw milk in French PDO cheeses. 


\subsection{Cross-analysis of two case studies}

\subsubsection{Consolidation of raw milk use in PDOs: new compromises}

The creation and history of the two PDOs fit within the general framework described above.

SN was granted the PDO in 1955 following a lawsuit won by farmhouse producers, most of whom owned large herds and extensive grasslands. They were successful in ensuring that the name of Saint-Nectaire was reserved for cheese made on farm premises after each milking. This socio-technical restriction of the PDO was immediately challenged by cheesemakers within the delineated geographical area whose milk was used in the making of Cantal cheese, or blueveined cheeses such as Bleu d'Auvergne (Brosse et al., 2014). The dispute was settled by government decision which stipulated that milk was allowed to be heated for curdling, thereby creating a lapse of time between milking and the beginning of cheese making process. This decision paved the way for dairy production and the deployment of industrial technologies such as storage of milk in refrigerated tanks on farm premises, standardisation of milk content, pasteurisation, addition of starter cultures and a shorter ripening time. Dairy production, which did not exist in 1963 , became the dominant mode in less than a decade, particularly after the creation of a large dairy cheese cooperative in the heart of the PDO area, with the result that in 1974 more than $60 \%$ of SN was dairy- produced (Ricard, 1994). In the conclusion of his thesis (1976), the Dutch geographer Tijms predicted that "the production offarmhouse Saint-Nectaire will gradually decrease to zero" (Tijms, 1976). The constraint of a twice-daily production, which required between 4 and 6 hours of work, and its seasonal variability were widely seen as insurmountable disadvantages compared to the industrial process. Farmhouse producers took another point of view.

The Ossau-Iraty PDO was created to overcome a crisis brought about by the withdrawal of Roquefort dairies from Western Pyrenees, where they had set up in the early $20^{\text {th }}$ century. In the 1970s, milk supply and cheese-making were relocated to their original area of production, in the southern Massif Central (Delfosse 2007). In response to this, certain livestock farmers retrained in farmhouse cheese production. Most of them turned towards local dairies specialised in the making of cow milk cheese. Keen to diversify their product range, the dairies supported the project of obtaining a designation of origin. The aim was to create a market for an industrial product having the image of a traditional sheep's milk cheese, like those still being made in the Pyrenees mountains. The livestock farmers involved in the initiative intended the PDO to bring together farmhouse cheese makers alongside milk producers and dairies in the Western Pyrenees, between Béarn (Ossau) and the Basque Country (Iraty). The specification was drawn up so as to be inclusive, stating simply that the milk should come from "traditional breeds", without clearly defining what that meant, and be curdled no more than 48 hours after the last milking, with no reference to the production technologies to be used. These choices ran counter to the whole image of traditional cheese as conceived of by the farmhouse producers, who were excluded from negotiations and consequently opted out of the PDO. They considered the rules to be so flexible that they would lead to a standardisation of the cheese, allowing such procedures as thermisation of the milk and artificial colouring of the rind. As a result, the largest dairies took over the designation and pushed in favour of greater productivity (Millet, 2019).

In both cases, the socio-technological pathways initially tended to align with the dominant regime. However, drastic shifts occurred at the end of the 1980s, as shown in the successive amendments to the specifications of the two designations [Figure 4] 
Figure 4 : Socio-technical pathways of Saint-Nectaire and Ossau-Iraty

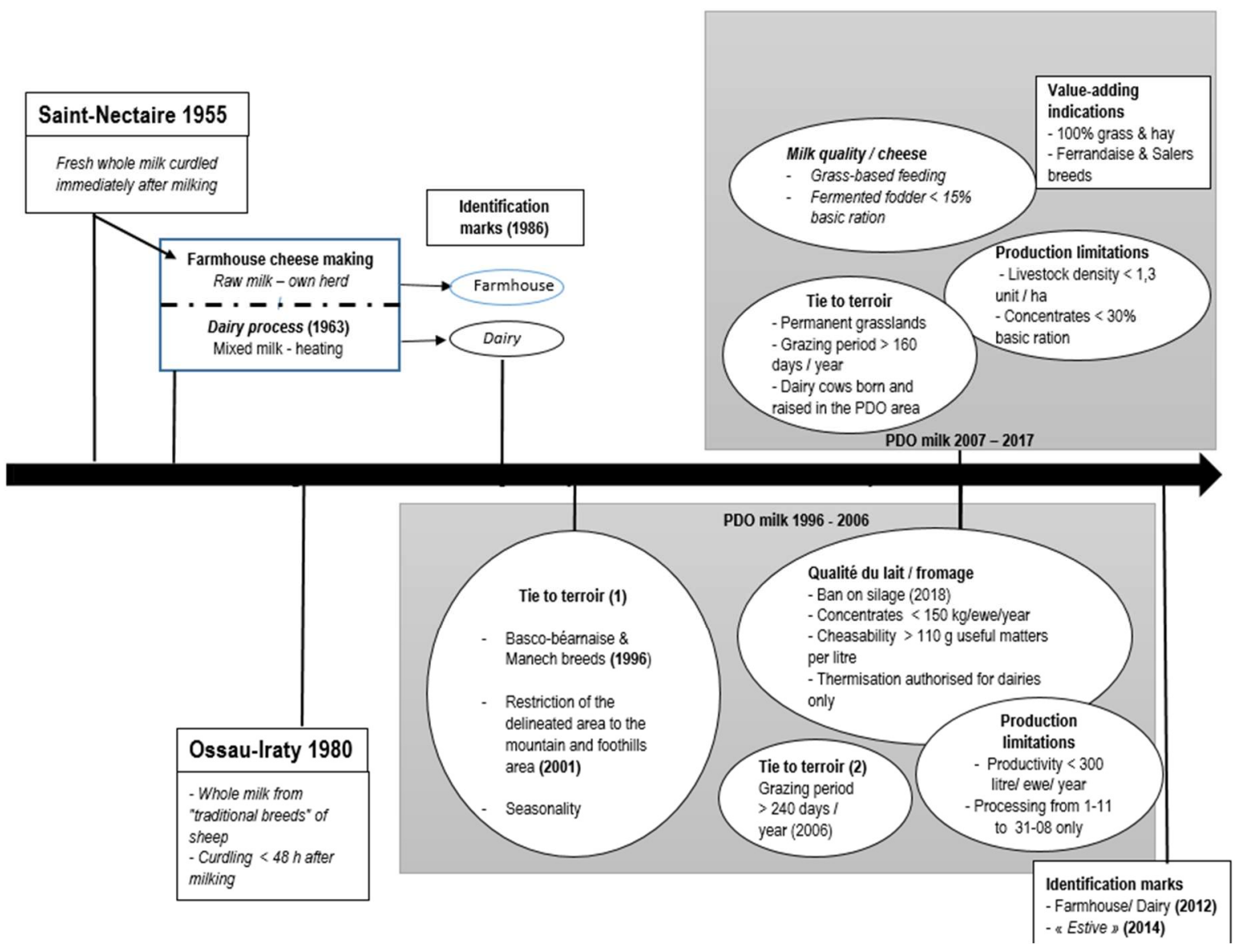

These major amendments are related to European harmonisation for the approval of national designations of origin. Refocusing on local resources has brought to light the obligation of representativeness and democratic functioning within the organisations that administer PDOs, a topic that is rarely dealt with in the literature on GIs (Marie-Vivien et al., 2019). In both cases, representation of the relevant stakeholders according to the volume of production has given way to a redistribution of decision-making power among the different categories of operators. The representation of milk producers alongside farmhouse cheese makers, dairy producers, and affineurs has been accompanied by a revision of the rules governing the designation of SN (2006), and by the distribution of power between milk producers, dairy producers \& affineurs and farmhouse cheese makers for that of OI. In the latter, the shift has been propelled by the active involvement in the governance of the PDO of farmhouse producers, who, although in the minority, alternate with dairy and milk producers as president of the ODG.

The change in the distribution of power is reflected in the agreements and compromises negotiated to make the case for a link between the quality of the cheese and the unique nature of its terroir. Two major strategic approaches have helped consolidate the status of raw milk in the two designations: $(i)$ differentiating between the technologies used in cheese-making by means of an identification mark, and (ii) opening up the black box of milk production systems. For all of the participants in the PDO, this meant reaching an agreement on what it is in the milk that gives the cheese its original character. Making a distinction between milk suitable for transformation into PDO cheese from "standard" milk is confrontational. The compromises 
reached and the time it took to make the transition, however, led to strategic options that broke with the regime.

Giving greater importance to the place of grasslands and grazing in the diet of dairy herds was the major stumbling block in negotiations. In the case of SN, there was fierce debate about a ban on using fermented fodder since it would entail investment in harvesting and drying equipment. Supporters of the use of hay, who were mainly farmhouse producers, won their case by turning around the hygienist argument in their favour. They maintained that fermented fodder promotes not only micro-organisms that are harmful to the taste of the cheese but also the presence of pathogens in the milk. The agreement on the ban on silage voted by members of the ODG was, however, overturned by the European Commission on the grounds of discrepancies between the deadlines proposed for the different non-minor amendments to the specification. Maintaining the use of silage is strictly regulated and offset by provisions that converge towards an enhanced sense of identification with the terroir. Grazing time has been lengthened and two labelling indications introduced: "The fodder on our farm(s) is composed exclusively of grazing and hay" and "made from milk obtained entirely from the Ferrandaise breed" (2017).

In the case of OI, the ban on using fermented fodder was required by farmhouse producers. This demand led to a split within the ranks of the ODG between farmhouse cheese makers and milk producers supported by the dairies (2003-2006). As was previously the case for the specification of local breeds (1996), an agreement was finally reached on grazing and hay as specific features of the Basque-Béarnaise agro-pastoral tradition and adjustment periods were allowed for the phasing out of fermented fodder (2018).

\subsubsection{Consolidation of the use of raw milk in PDO cheeses: the result of drawing dividing lines}

The increasing share of raw milk cheese in overall production was due to the distinction made between farmhouse products and dairy products, which both bear the same designation in the marketplace.

Farmhouse and dairy SN cheeses were distinguished from 1986 onwards by different identification marks applied on the rind, which signalled the segmentation of their respective markets, thereafter relatively separate and complementary. Ripened farmhouse cheeses (weighing 1.4 to $1.9 \mathrm{~kg}$ ) are sold individually, direct from the farm or by specialty retailers, whereas cheeses made from pasteurised milk are mainly found in large retail outlets and collective catering after being cut up and packaged in portions. The mould that develops on the rind of farmhouse SN during the ageing process makes it unsuitable for plastic wrapping and gives it a distinctive appearance visible to the naked eye. The affineurs, who transform green cheese into the ripened product, underline this technological distinction and use to their advantage the farmhouse designation for cheese sold under their own brand.

Making a distinction between the two modes of production is more problematic in the case of OI. The rind of the cheese is regularly brushed during ripening so that pasteurised and farmhouse products look alike externally. In addition to this, the Béarn farmhouse cheese, which weighs between 4 and $5 \mathrm{~kg}$, is sold sliced outside of retail circuits. Since 2012, farmhouse producers have been allowed to use identification marks on the rind affixed by means of punches to distinguish their cheese (F) from the dairy product (L). In addition, Béarn "estive" cheeses were identified by the Slow Food Foundation for Biodiversity as an exceptional product 
that needed to be safeguarded, as they are made by transhumant shepherds on mountain pastures during the summer season. Several farmhouse cheese representatives joined the Slow Food movement and incorporated its "estive" identification mark into the OI specifications, thereby creating an added value for the raw milk product. This initiative brought together farmhouse producers and shepherds, who were overwhelmingly opposed to the industrialisation of traditional ewe's milk when the PDO was created (Mariani et al., 2019).

However, these stamps are thought to be hard to identify by the consumer. In addition, the distinction between farmhouse and dairy cheese fails to successfully differentiate OI cheeses made from raw milk by dairies. For cheesemakers and milk producers, raw milk constitutes a risk but is also an asset since it distinguishes them from their industrial rivals, who use heattreated milk. Respect for the specific characteristics of the milk, which are dependent on farming practices and milking conditions, results in price differentials for milk producers: the payment grid is more stringent in terms of hygiene criteria but more profitable financially. The only way that dairies which make cheese from raw milk can signify their difference is by the reference "Made from raw milk" printed on their cheese label. These dairies are small and medium businesses, have a small number of milk suppliers, process low volumes and lack sufficient representation in the ODG. Consequently, they opted for endorsing other development projects, such as "family farming" in the case of the Azkorria cooperative and "organic farming" in the case of Garazi.

This cross-analysis shows that the visibility of raw milk cheeses in the marketplace and the media can be attributed to farmhouse producers, whose products are now clearly identified within the respective PDOs and in general acknowledged to have a superior status to those made with heat-treated milk. This is notable for the SN designation, where the price of a litre of milk rises from $0.34 €$, i.e. the price of standard milk, for a milk producer to $0.8-0.9 €$ for a farmer selling green cheeses. The low price paid for milk supplied to dairies goes hand in hand with the industrial producers' lack of interest in its quality, even when they accept to pay a bonus for milk suitable for transformation into PDO cheese, as in the case of OI, for which the price is 5 to $8 \%$ higher than that of standard ewe's milk. Although $80 \%$ of the milk produced in the area covered by the designation could be transformed into OI, only $30 \%$ is in fact used for that purpose. Mixing of milks, as performed in industrial dairies, is motivated by the desire to bring down collecting costs.

\subsubsection{Flow of milk, cheese and resources between operators: a controlled movement}

Although it does not always result in an improved status and increased value of raw milk within the different PDO cheeses, highlighting differences in cheese-making techniques can sometimes be very effective as a lever in guiding the action of the ODGs.

The distinction between dairy technology and farmhouse practices in the production of SN gave rise to an ODG survey (1995) on how to control health risks for farmhouse and dairy cheese makers. A subsequent study focused on the grading of green and ripened cheeses and the development of a scoring grid (physical and organoleptic characteristics). Supplying each producer with a set of guidelines resulted in a marked improvement in quality, particularly for farmhouse SN. Although the ODG is currently financed by the contributions of all categories of operators, priority is given to raw milk in the distribution of collective resources, whether for the staff (4 out of 6 employees are cheese technicians), risk management (adaptation of the Hazard Analysis Critical Control Point method to farmhouse conditions, destruction of batches 
of products not meeting safety requirements) or research and development (cheese grading system).

This situation shows the symbolic importance of raw milk in its ability to reveal the ties that bind cheeses to the terroir. It also evidences the food safety issues involved in raw milk management. While dairies can be credited with $50 \%$ of the increase in OI cheese made from raw milk, none for the moment have taken the same risk with SN. With authorisation to collect a maximum of two successive milkings, making dairy SN from raw milk entails a drastic reorganisation of the logistics of dairy work practices. This step is easier to take for the OI, for which the time between milking and curdling can be up to 48 hours. Artisan dairy producers that convert to raw milk technology nevertheless maintain a production line with thermisation: not all milks are suitable for the making of raw milk cheese and so they divide up the milk collected daily according to what it will be used for.

For SN cheese, almost a third of the milk delivered to dairies comes from farmhouse cheese producers. Dairies offer them the possibility of dispensing with the constraint of making cheese on the weekend and the ability to treat their milk in the event of contamination. Not having to destroy milk while the problem is being solved provides a form of security for farmhouse cheese producers. Not all producers, however, are offered this security, which depends on the individual dairy's collection area. Likewise, in OI, certain farmers are cheese makers during the transhumance season and milk sellers the rest of the year.

In both areas of PDO, most affineurs age the two types of cheese in their cellars. Certain dairies ageing their own pasteurised SN do the same with green cheeses bought from farmhouse producers. Such dairies thus build up a range of products while contributing to the progression of farmhouse cheese production. For OI, green cheese is generally ripened by cooperatives and specialised affineurs on behalf of farmhouse producers. These ripening businesses also provide the service for non-PDO products and those made from raw milk or pasteurised milk from cows, ewes and goats (Profession Fromager, 2019)

\section{4 - DISCUSSION}

Three salient points about the coexistence of raw and pasteurised milk in cheese designations of origin emerge from the cross analysis of our case studies. They relate to $(i)$ the stakeholders involved and their respective status, (ii) raw milk itself and the various contexts in which it is used and (iii) the types of regulation governing the terroir niche and the different levels at which they operate. We will discuss these points to see how they might validate our original hypothesis.

\section{1 - Deconstructing the opposition between farmhouse and dairy cheese makers: internal heterogeneity of the terroir niche}

Analysing the conditions under which the two types of production exist side by side and examining the stakeholders involved, their different practices and various legitimacies lay the ground for the deconstruction of the opposition between farmhouse and dairy cheeses.

Raw milk is only used by farmhouse cheese-makers in the case of SN whereas raw milk cheese is clearly an option taken up by dairies that worked only with heat-treated milk in the case of OI. More broadly speaking, the progression of raw milk in PDO cheeses is not due solely to 
farmhouse producers. With the exception of Salers and Chevrotin, which are exclusively farmhouse cheeses, and Comté and Roquefort, which are exclusively dairy products, the other PDOs banning heat treatment include farmhouse and dairy cheese makers.

At this stage of the analysis, it is important to identify which dairy operators are able to work with raw milk. In the case of OI, they belong to small or medium-sized enterprises that use artisan production methods. It is not necessary to make a systematic analysis of PDO cheeses to be aware that handling large volumes of milk to be transformed without heat treatment poses genuine difficulties. Making raw milk cheese relies on a network of processing facilities placed between farmers on one side and large dairies that deal with numerous milk suppliers on the other. This in-between position has a particular configuration in which the relations between the operators are much closer and values more easily shared (Millet and Casabianca, 2019). In addition to the specific characteristics of the various cheeses, these values affect both the milk itself and its mode of production and progressively pave the way to the sustainability of their activity. Such operators break with a process that has undermined the legitimacy of the PDOs and prevented thinking of a state of coexistence in terms other than the dichotomy of raw milk/farmhouse producer $v s$ pasteurised milk/industrial producers. In addition, they have opened up opportunities to create alliances within ODGs to advance their case in the drawing up of common rules.

Our analysis also shows that there is another state of coexistence during the ageing process, when the two types of milk can be found in the same maturing cellar where they share the same microbial environment. These conditions of proximity promote the exchange of microbial flora on the rind that can be important in the final stages of cheese production in terms of appearance and taste. Our case studies evidence a recent trend not yet confirmed over the long term. Large dairy companies have adopted a new strategy of buying green farmhouse cheeses via their local subsidiaries with the aim of developing a range of products including the two types of cheese. Under this system, farmhouse producers entrust the ageing of their cheese to industrial dairies, which provide the necessary capital for storing and marketing the cheese once it is ripened. In this way, the dairies that ripen farmhouse cheeses contribute indirectly to the development of raw milk farmhouse production.

One controversial issue is use of the term "farmhouse", which figures on cheese sold by the affineurs without mentioning the name of the farmer who curdled the milk. This practice allows industrial dairies to tap into the reputation of farmhouse cheeses without having to assume the risks inherent in the transformation of raw milk. This strategy seems to us to be a means of outsourcing health risks.

\section{2 - Tensions in the perception of microbes: "There is raw milk and raw milk"}

Raw milk requires adaptive skills and the ability to work with a living and variable matter whose behaviour is difficult to predict. Farmhouse cheese-makers increase the chances of achieving a favourable outcome by transforming the milk of their own animals (which they know, care for and follow individually) as soon as milking is over or the milk is mixed with that of the previous milking. They limit thereby the possible risks of deterioration caused by refrigeration and transport. Artisan dairy cheesemakers working with raw milk possess other types of skill acquired through the close monitoring of "their" suppliers. They pay a particular attention to sorting the milk collected and deciding on whether to pasteurise when necessary. The skills required for processing pasteurised milk are of a different order, such as dealing with large 
volumes, efficient control of the manufacturing parameters and careful dosing of the starter cultures added to heat-treated milk.

Knowing how to manage microbial ecosystems is a major skill required in all types of cheese production, particularly those using raw milk, which are exposed to a greater risk of being contaminated by harmful germs. However, as emphasized by the president of the $\mathrm{SN}$, who is a farmhouse producer, it is important to establish what raw milk means, in terms of how it is used and with what aim, "For me, there are two raw milks - even if you call them by the same name. There's the method whereby you manage the risks from the very beginning- the soil, the pasture, the animal, the barn, the milking parlour and so on- and you express in the raw milk everything that has happened beforehand. Then there's the other method, which is all about making everything hygienic, using great doses of starter cultures, even adding artificial aromas ... If you want to defend raw milk, better do it with the first method and not with the second."

If there is an excessive focus on hygiene, raw milk can end up resembling pasteurised milk: it will be poor in micro-organisms so that the acidification process will require the massive addition of starter cultures. In this form the milk no longer acts as a vector of the microbial specificity of the terroir. It can then be processed by both farmers and dairies according to standard techniques, with the exception of heat treatment; the taste and texture of the cheese will depend largely on the cultures added and the subsequent process used. The other sort of raw milk, which still bears witness to its origin, generally has a more evenly balanced native flora which is favourable to cheese making. Depending on whether the native flora manages to develop or the added starters gain the upper hand, the specific characteristics of the cheese risk being lost. With the support of socio-technical networks (for example, the Réseau mixte technologique Fromages de terroir), different PDOs have sought to identify and manage reservoirs of useful flora such as teats and bedding to obtain richer and more diversified raw milks (Montel et al., 2014). Likewise, in other PDO areas such as the Savoie, production strategies have been developed using locally made starters with the aim of giving all producers an alternative to industrial starters and thereby preserving their products' typicality. Finally, to maintain the microbial environment of the farm, attempts have been made to develop indigenous whey starters, essentially through grafting, that would consolidate the flora already present (Mariani et al., 2019). Although these initiatives have a limited effect for the moment, they are evidence of the interest aroused by the management of microbial ecosystems and the production of "natural" cheeses promoted by the Slow Food movement.

Revision of the rules governing production, undertaken in a growing number of PDOs, in particular the ban on fermented fodder and limiting animal productivity, should be seen in regard to the method of management of health risks "from the very beginning". Working with raw milk with confidence and allowing its authentic expression in the cheese thus requires a reconnection with the functioning of the agri-ecological system from which it originates (de Sainte Marie and Bérard, 2015; Percival and Percival, 2017).

\section{3 - Strategic management of the niches: means of regulation}

From our theoretical framework it emerges that stakeholders in the different PDOs have to manage the relationship between their terroir niche and the dominant regime. Which strategies are effective in counteracting the adoption of standard solutions, which would result in the simplification of the niche? Would a radical approach like banning pasteurisation guarantee the long-term sustainability of the terroir niche? Our analysis identifies the multi-level regulatory 
mechanisms that maintain the coexistence of different technologies and modes of production within the niche.

\subsubsection{Governance of the terroir niche and protective mechanisms}

The technical support and assistance that farmhouse producers receive from the PDO authorities is the first major evidence of the collective ability to promote coexistence and to counteract the trend towards the generalized use of pasteurised milk. One approach would be to mutualise resources and their deployment. Priority is sometimes clearly given to raw milk (as in the case of SN), by investment in the management of workplace risks run by farmers and artisan producers and assistance in the event of an accident (Ricard, 1998). In other cases (such as that of OI), technical support for raw milk producers is outsourced while the PDO's own resources are devoted primarily to the commercial promotion of the designation. This runs the risk of exploiting the reputation of raw milk for the benefit of all the designation stakeholders without making any distinction between the technical and commercial choices they may have made. The approach adopted by the PDOs for the use of collective resources would therefore appear to be favourable to maintaining coexistence provided that care is taken to preserve proper balances within the niche.

The central issue in the regulation of the terroir niche, therefore, is how to decouple the value accorded to PDO milk from that of the standard milk. The recent changes in direction taken by the governance of PDO cheeses in France can be interpreted from this perspective. In line with product specification amendments (Quiñones Ruiz et al., 2018), new requirements for livestock systems aim at making PDO milk a specific good. For this qualitative strategy to be viable, the differential value would have to be passed on by the dairies to their suppliers. PDO milk producers must be paid a sufficient price for their milk to make it worthwhile to continue in business. In the SN designation area, larger agricultural holdings have shifted from milk to cheese production, which can guarantee a higher level of remuneration provided that the work with raw milk is properly accomplished. In contrast, for larger dairies shifting from pasteurised to raw milk presents significant challenges. Since the specifications for PDO milk have been tightened, the cost of changing a livestock system has increased. Both milk producers and dairies are subject to the tensions that arise from the transition process. For dairies working solely with pasteurised milk the option of switching over to raw milk has become a viable option. In SN, however, none has yet made that choice. Changes in direction in PDO pathways have brought to light lock-ins in the evolution of operators.

The average size of agricultural holdings in France has been steadily increasing, albeit to a lesser extent in PDO areas. If this trend were to continue it would threaten raw milk production, which needs medium-sized herds and facilities in order to control the different sources of contamination, like the co-operatives of the Franche-Comté region ("fruitières"), which produce between 50 and 500 tonnes of cheese per year. A major challenge for the PDO authorities in the strategic management of these niches is to ensure over the long term as much diversity as possible in the size of agricultural holdings.

The coexistence of two types of milk within the same designation gives rise to the notion of a project, defined as "the reasons and ends that a collective gives itself to turn its action towards a desired future" (Le Velly, 2019). One indicator of a project is the way in which the PDOs develop and modify the contents of their specifications and the priorities of their programme of action to achieve the "promise of difference" of their products. A dynamic balance needs to be established between the generational long-term perspective of local farmers and artisans and 
the shorter-term vision of the managerial staff of the local subsidiaries of the large dairy groups, who frequently move from site to site.

In all events, one of the factors that corporate interests cannot control is the PDO governance architecture. Unlike trademarks, PDOs are collective property rights owned by local operators and controlled by their representatives. This local regulation is itself under public authority, which guarantees the balance of power within the producers' organization and respect for PDO guiding principles (Marie-Vivien et al., 2017). French and European authorities have made great efforts to achieve official recognition of the status of GIs and to ward off free-trade opposition to it. In return, they were required to demonstrate the mutual connection between the quality of the product and its natural and cultural place of origin. Integration of the conditions of milk production has tended to consolidate the status of farmhouse cheesemakers and, to an even greater extent, that of producers of milk of a specific quality. Reference to the general principle - the tie to the terroir - seems to be an effective strategy in counteracting generic solutions, such as milking robots, within the niche.

The evolutions observed emphasise the major role played by the INAO and the European Commission in the drawing up of guidelines on the democratic character of the governance of designations of origin and on the fundamentals of their specifications. They open up opportunities for change for those committed to achieving the coexistence in PDOs of raw and pasteurised milk.

\subsubsection{Strategic management of the niches: theoretical contributions of our work}

Our findings strongly suggest that internalising the confrontation between niche and regime within the complex niche could create a systemic transformative potential once the coexistence of raw and pasteurised milk has been settled.

At the national level, analysis of cheese designations of origin highlights two simplification mechanisms in the terroir niche: the exclusive use of raw milk and the generalized use of pasteurisation. In the first case, the decline in the production of Roquefort and Salers show that a radical break with the regime is no guarantee of the sustainability of the niche unless it is turned into a regional sub-regime. Comté cheese in the Jura mountain and Beaufort in the Northern Alps succeeded in doing this by associating the ban on pasteurisation with an agricultural model based on small-scale processing and presenting themselves as integral components of the terroir (Bowen, 2010). In the case of generalized pasteurisation, the confrontation between modes of production has led to the niche being diluted in the regime, as with Bleu d'Auvergne and Epoisses cheeses, which are almost exclusively made in dairies and with pasteurised milk. Cantal, Munster and Maroilles at present are at a crossroads.

At a local level, our case studies show that alignment with the regime, under certain conditions that we have identified, is not necessarily irreversible. Our findings suggest that allowing pasteurisation opens up the possibility of including a greater number in the decision-making process and more particularly a wider range of stakeholders such as milk producers, dairies and specialised affineurs, who are often the weak links in the system. Expansion of the network of local actors will create new alliances within the niche by modifying the power relationships. The growing consumer demand for raw milk cheese is a powerful force in the making of internal policy choices and gives a boost to the whole local system. Certain socio-technological pathways are taking shape in which protection will promote innovation and thus sustain the niche over time. 
The internalised confrontation of niche $v s$ regime within the complex niche emphasizes that to encourage coexistence, the regime's pressure to standardize must be offset by a governance that looks to enhanced relations in the production environment. The terroir, by stimulating interactions within the agro-ecological system, is the best defence against simplification. Raw milk, which expresses the natural flora of the production environment, is an integral part of this protection. A long-term vision can draw on these defences and create a strategic management that maintains balance within the system. A terroir niche (Belmin et al., 2018) includes protection mechanisms in which reconnecting with local resources contributes to the same aim of achieving a distinctive profile in the marketplace. These processes of mutual consolidation place the terroir at the heart of long-term management strategy.

Our theoretical approach is in line with that of scholars in the emerging field of the geography of transitions (Lawhon and Murphy, 2011; Truffer and Coenen, 2012; Hansen and Coenen, 2015). These authors point out that the aim is not so much to investigate the relationship between niche and regime as to focus on the internal dynamics of the niches themselves that make coexistence possible. The geographically situated nature of the functioning of the terroir niches entails taking into account not only the resources in which local activity is grounded but also the interaction of networks, norms and values that shape formally and informally how the local actors behave (Raven et al., 2012). The place-based nature of these elements means that particular attention is paid to the fine framework within which coexistence takes place (locally made arrangements and the "silent" innovations that make it effective) and that, at the same time, account is taken of its interconnection with local and supra-local regulations. In addition, our work highlights the different time and space levels relevant to providing an account of the dynamics at work.

\section{CONCLUSION}

This in-depth analysis of the evolution of raw milk cheese production at a national level and in two local situations (Saint-Nectaire and Ossau-Iraty) provides a counter argument to the claim that raw milk and pasteurised milk production cannot exist side by side within PDOs. More general lessons can be drawn from the example of raw milk on the problematic notion of the coexistence of different farming and food provisioning models through the prism of the dynamics of legitimisation and disqualification (Plumecocq et al., 2018).

Our approach to this coexistence was focused on the tensions between regime and niche within the terroir niche. However, this complex niche should be seen in the broader socio-technical landscape. From a multi-level perspective, its role can be decisive in destabilising the regime and fostering niches of innovation. In our analysis, this landscape is ambiguous and full of contradictory tensions. The regulatory obligation to use pasteurised milk has been overridden on several occasions but raw milk cheeses are still stigmatised by the health authorities, which classify them as high-risk products. At the same time, there is growing consumer demand for more natural foods, with raw milk being seen as a beneficial element in their diet. Despite warnings about the potential danger of raw milk cheeses, their consumption is continuously growing. The campaign for the defence of raw milk is supported by the Slow Food movement, which has made it a major argument in the re-establishment of the citizen's right of choice. For its part, the French Academy of Medicine attests to the beneficial effects of the consumption of raw milk in protecting against allergies and auto-immune diseases (Vuitton et al., 2019). 
The controversy surrounding the status of Camembert cheese, with which we introduced the present article, has put into perspective the contention that PDOs which allow the use of pasteurisation compromise cheese quality. As demonstrated in our case studies, the coexistence of raw milk and pasteurised milk in cheese production does not necessarily result in the elimination of the former. However, the policy of zero tolerance risk has made raw milk cheese particularly vulnerable to any passing crisis unless consumers take up arms in its defence (West, 2008). A media blackout of designations of origin could unintentionally undermine raw milk cheeses by depriving them of the crucial support of public opinion.

Our results confirm the interest of the Multi-Level Perspective and of the strategic niche management approach as relevant conceptual and methodological frameworks to fully consider the dynamics of coexistence of contrasted models and their confrontation.

\section{Note}

This paper arose out of work carried out in the INRA/CIRAD multidisciplinary programme entitled "REPASTOL Retour sur l'évidence pasteurienne" (GloFoodS 2015-2017). We would like to sincerely thank the two anonymous reviewers who made helpful suggestions on the analytical framework and the restructuring of the text.

\section{REFERENCES}

Agreste 'Enquêtes annuelles laitières (Annual Dairy Surveys)'. Ministère de l'Agriculture.

Barham, E., \& Sylvander, B. (2011). Labels of Origin for Food: Local Development, Global Recognition. Wallingford, UK: CAB International.

Belmin, R., Casabianca, F., \& Meynard, J.-M. (2018). Contribution of the transition theory to the study of Geographical Indications. Environmental Innovation and Societal Transitions, 27, 32-47.

Bérard, L., \& Marchenay, P. (2007). Localized products in France: definition, protection and value-adding. Anthropology of food, (S2 March).

Bowen, S. (2010). Embedding Local Places in Global Spaces: Geographical Indications as a Territorial Development Strategy. Rural Sociology, 75(2), 209-243.

Brosse, A.-L., Hulin, S., \& Piccoli, B. (2014). Fromages d'Auvergne. Une histoire d'hommes et de femmes. Aurillac: Quelque part sur terre.

Casalegno, E., \& Laske, C. (2016). Les cartels du lait. Paris: Don Quichotte.

Colletis-Wahl, K., \& Pecqueur, B. (2001). Territories, Development and Specific Resources: What Analytical Framework? Regional Studie 35(5), 449-59.

de Sainte Marie, C., \& Bérard, L. (2015). Taking Local Knowledge into Account in the AOC system. In M. Blackeney (Ed.), Geographical Indications, Vol. 1 (pp. 585-592). Cheltelham, UK Edward Elgar.

Delfosse, C. (2007). La France fromagère (1850-1990). La Boutique de l'Histoire.

Dumont, A., Gasselin, P., \& Baret, P. (2020). Transitions in agriculture. Three frameworks highlighting coexistence between a new agroecological configuration and an old, organic and conventional configuration of vegetable production in Wallonia (Belgium) Geoforum (108), 98-109. 
El Bilali, H. (2020). Transition Heuristic Frameworks in Research on Agro-Food Sustainability Transitions. Environ Dev Sustain, (22), 1693-1728.

Geels, F. W. (2002). Technological transitions as evolutionary reconfiguration processes: a multi-level perspective and a case-study. Research Policy, 31(8-9), 1257-74.

Geels, F. W., \& Schot, J. (2007). Typology of sociotechnical transition pathways. Research Policy (36), 399-417.

Goodman, D. (2003). The quality 'turn' and alternative food practices: reflections and agenda. Journal of Rural Studies, (19), 1-7.

Hansen, T., \& Coenen, L. (2015). The Geography of Sustainability Transitions: Review, Synthesis and Reflections on an Emergent Research Field. Environmental Innovation and Societal Transitions, (17).

Köhler, J., \& et al. (2019). An Agenda for Sustainability Transitions Research: State of the Art and Future Directions. Environmental Innovation and Societal Transitions, (31), $1-32$.

Lamine, C., Renting, H., Rossi, A., Wiskerke, C., \& Brunori, G. (2012). Agri-Food Systems and Territorial Development: Innovations, New Dynamics and Changing Governance Mechanisms. In I. Darnhofer, D. Gibbon, \& B. Dedieu (Eds.), Farming Systems Research into the 21st Century: The New Dynamic (p. 229-56). Dordrecht: Springer

Lawhon, M., \& Murphy, J. T. (2011). Socio-technical regimes and sustainability transitions: Insights from political ecology. Progress in Human Geography, 36(3), 354378.

Le Velly, R. (2019). Allowing for the Projective Dimension of Agency in Analysing Alternative Food Networks. Sociologia Ruralis, 59(1), 2-22.

Libération. (2018). C'est le camembert de Normandie AOP au lait cru qu'on assassine, May 14.

Licitra, G. (2010). World wide traditional cheeses: Banned for business? Dairy Sci. Technol., (90), 357-374.

Mariani, M., Cerdan, C., \& Peri, I. (2019). Contested knowledge: changing practices in origin-food communities. British Food Journal, 121(12).

Marie-Vivien, D., Bérard, L., Boutonnet, J.-P., \& Casabianca, F. (2017). Are French Geographical Indications Losing Their Soul? Analyzing Recent Developments in the Governance of the Link to the Origin in France. World Development, 98, 25-34.

Marie-Vivien, D., Carimentrand, A., Fournier, S., Cerdan, C., \& Sautier, D. (2019). Controversies around geographical indications. Are democracy and representativeness the solution? British Food Journal, 121(12), 2995-3010.

Markard, J., Raven, R., \& Truffer, B. (2012). Sustainability Transitions: An Emerging Field of Research and Its Prospects Research Policy, 41(6), 955-67.

Millet, M. (2019). From Ossau and Iraty to PDO Ossau-Iraty. The long-term construction of a product based on two distinct places. British Food Journal, 121(12).

Millet, M., \& Casabianca, F. (2019). Sharing Values for Changing Practices, a Lever for Sustainable Transformation? The Case of Farmers and Processors in Interaction within Localized Cheese Sectors. Sustainability, 11(17). doi:10.3390/su11174520 
Montel, M. C., Buchin, S., Mallet, A., Delbes-Paus, C., Vuitton, D. A., Desmasures, N., et al. (2014). Traditional cheeses: Rich and diverse microbiota with associated benefits. International Journal of Food Microbiology, (177), 135-154.

Paxson, H. (2008). Post-pasteurian cultures: The microbiopolitics of raw-milk cheese in the United States. Cultural Anthropology, 23(1), 15-47.

Peltier, E. (2018). French Cheese Rules Denounced as 'Treason' New York Times, May 17.

Percival, B., \& Percival, F. (2017). Reinventing the Wheel. Milk, Microbes and the Fight for Real Cheese. London \& New York,: Bloomsbury Sigma.

Plumecocq, G., Debril, T., Duru, M., Magrini, M.-B., Sarthou, J.-P., \& Therond, O. (2018). The Plurality of Values in Sustainable Agriculture Models: Diverse Lock-in and Coevolution Patterns. Ecology and Society, 23(1). doi:10.5751/ES-09881-230121.

Profession Fromager. (2019). Le guide des fromages au lait cru. Lille: Editions ADS.

Quiñones Ruiz, X., Forster, H., Penker, M., Belletti, G., Marescotti, A., Scaramuzzi, S., et al. (2018). How are food Geographical Indications evolving? An analysis of EU GI amendments. British Food Journal, 120(8), 1876-1887.

Raven, R., Schot, J., \& Berkhout, F. (2012). Space and Scale in Socio-Technical Transitions. Environmental Innovation and Societal Transitions, (4), 63-78.

Raven, R., Van den Bosch, S., \& Weterings, R. (2010). Transitions and Strategic Niche Management: Towards a Competence Kit for Practitioners. International Journal of Technology Management, 51(1), 57-74.

Ricard, D. (1994). Les montagnes fromagères en France. Clermont-Ferrand: Université Blaise Pascal.

Ricard, D. (1998). Produits de terroirs et normes de fabrication. Les fromages d'AOC face aux nouvelles exigences sanitaires. Revue de géographie alpine, 86(4), 103-114.

Richez-Lerouge, V. (2017). Main basse sur les fromages AOP. Comment les multinationales contrôlent nos appellations. Paris: Erick Bonnier.

Schot, J., \& Geels, F. W. (2008). Strategic Niche Management and Sustainable Innovation Journeys: Theory, Findings, Research Agenda, and Policy Technology Analysis \& Strategic Management 20(5), 537-54.

Sciolino, E. (2007). If Rules Change, Will Camembert Stay the Same? The New York Times, June 20.

Sylvander, B., \& Biencourt, O. (2006). Negotiating standards for animal products: a procedural approach applied to raw milk. In J. Bingen, \& L. Bush (Eds.), Agricultural Standards. The Shape of the Global Food and Fiber System (pp. 95-110). Springer.

Tijms, W. (1976). Le Saint-Nectaire. L'histoire d'un fromage d'Appellation d'origine dans son cadre géographique et économique. Groningen:

Torre, A., \& Traversac, J.-B. (2011). Territorial Governance: Local Development, Rural Areas and Agrofood Systems. Springer Science \& Business Media.

Trubek, A. B., \& Bowen, S. (2008). Creating the taste of place in the United States: can we learn from the French? GeoJournal, (73), 23-30. 
Truffer, B., \& Coenen, L. (2012). Environmental Innovation and Sustainability Transitions in Regional Studies. Regional Studies, 46 (1), 1-21.

Turnheim, B., Berkhout, F., Geels, F., Hof, A., McMeekin, A., Nykvist, B., et al. (2015). Evaluating Sustainability Transitions Pathways: Bridging Analytical Approaches to Address Governance Challenges. Global Environmental Change, 35, 239-253.

Vuitton, D. A., Divaret-Chauveau, A., Dalphin, M.-L., Laplante, J.-J., \& Dalphin, J.-C. (2019). Protection against allergy by farm environment: What have we learnt from the PASTURE European Children Cohort? Bulletin de l'Académie Nationale de Médecine 203(7), 618-630.

West, H. (2008). Food fears and raw-milk cheese. Appetite, (51), 25-29. 